\title{
The Construction and Application of Project-Case Teaching Platform Based on Moodle Environment
}

\author{
Ma Yongqiang \\ Computer Department of JiNing normal university \\ nsd-myq@126.com
}

\begin{abstract}
At present, online teaching platform is applying and promoting gradually. Course management systems have matured rapidly and now are considered critical software for many universities, the Moodle is an open and perfect source course management system. By analyzing the characteristics of specialized courses and learning situation of students majoring in computer science and technology of Computer Department of Jining Normal University, this paper analyzes its feasibility to construct the project-case teaching platform and then builds the platform based on Moodle.finally we take the "theory and technology of CAI" course as an example to apply and test the teaching platform.
\end{abstract}

Keywords: Moodle; Project-case; Teaching Platform

\section{The Analysis of Students' Current Situation and Course Characteristics}

With expansion of college enrollment, students' cultural quality has been reduced to a large degree. The situation is more serious especially in some vocational colleges. The freshmen have weak foundation and bad habits in study. It brings about new challenges for the current higher education and new difficulties for teaching and management. This situation seriously affects the teaching quality and students' comprehensive quality. Moreover, students lack learning initiative. Most students take a "painful" and "forced" attitude to learn. They have no learning objectives and driving force in study. These internal and external factors lead to the students learning difficulties, the lack of confidence in learning and the learning weariness.

Project-case teaching is a new blended teaching mode that integrates the project teaching with the case teaching. It will arrange a complete project before the beginning of the course. In the process of teaching it will give students many examples to help students to complete the project and realize the teaching goals of the course. Its main purpose is to encourage students to integrate knowledge learning with the completion of the project and to make students improve themselves actively. A characteristic of most specialized courses in major of Computer Science \& Technology is the theory and practice combination. Also, they emphasize the practical ability and innovation.

Thus, these courses are very suitable to use "project teaching" + "case teaching" teaching mode. However, if the teaching effect is not particularly good under the traditional environment, we should choose a more appropriate teaching platform to implement the project-case teaching.

Moodle was designed and developed by Dr. Martin Dougiamas in Australia. It is a completely free online-course teaching and administration platform. Moodle is based on the theory of constructivism, which precisely corresponds to the above-mentioned examples of teaching philosophy. If we integrate the various teaching cases and project 
tasks with the Moodle system and make use of discussion area, WiKi and other functional modules of the system to carry out teaching activities, it will have a good effect.

\section{The Feasibility Analysis of Project-Case Teaching Based on Moodle}

\subsection{Introduction to Moodle}

Moodle is the full name of Modular Object - Oriented Dynamic Learning Environment. The Chinese meaning is modular object-oriented dynamic learning environment. It is a software package for the construction of network teaching website. It is an open source software with powerful functions. It can be easily operated.

The open nature of Moodle system determines that it is completely free in the process of use and later upgrade. Moodle package code is completely open to the public. At the same time, the Moodle community has provided us a lot of third-party modules plug-in. We can add the corresponding module according to the need. Of course, the system can also be developed for the second time to meet the personalized needs of the system users. It includes three parts: language pack, theme and independent development of function module.

\subsection{The Comparison between Functions of the Moodle System and Project- Case Teaching Environment}

Through the analysis of the project-case teaching environment and main functions of the Moodle, we can get specific circumstances of each function module as shown in Table 1.

Table 1. Comparison of Functions

\begin{tabular}{|l|l|}
\hline \multicolumn{1}{|c|}{ Project-case Teaching Environment } & \multicolumn{1}{c|}{ Main Functions of Moodle } \\
\hline $\begin{array}{l}\text { The teacher can upload all kinds of } \\
\text { learning resources, students can easily } \\
\text { learn online or download the materials to } \\
\text { learn }\end{array}$ & $\begin{array}{l}\text { The Moodle system supports the } \\
\text { display of multi-media Word, } \\
\text { PowerPoint, Flash, sound, animation, } \\
\text { video, providing online learning or } \\
\text { download to learn }\end{array}$ \\
\hline $\begin{array}{l}\text { Teachers can give students specific } \\
\text { tasks. Students can easily submit their } \\
\text { finished products. }\end{array}$ & $\begin{array}{l}\text { The homework- module of the Moodle } \\
\text { system can realize the functions of } \\
\text { teachers' assigning homework and } \\
\text { students' uploading tasks. }\end{array}$ \\
\hline $\begin{array}{l}\text { To support the online exam; to realize } \\
\text { the automatic grading; tests cover a } \\
\text { variety of topics; to output student } \\
\text { achievement table } \text { etc.. }\end{array}$ & $\begin{array}{l}\text { To define the item bank; automatic } \\
\text { grading system; to support several types } \\
\text { of topics; to output various grades } \\
\text { tables. }\end{array}$ \\
\hline $\begin{array}{l}\text { Project-case teaching attaches great } \\
\text { importance to the diversification of } \\
\text { evaluation and teaching reflection }\end{array}$ & $\begin{array}{l}\text { The Moodle system supports multiple } \\
\text { evaluation, including self-evaluation, } \\
\text { partener-evaluation, teacher-evaluation, } \\
\text { process-evaluation and summative } \\
\text { evaluation } \text { etc... }\end{array}$ \\
\hline $\begin{array}{l}\text { Teachers' and teacher-student's effective } \\
\text { interaction through a variety of ways }\end{array}$ & $\begin{array}{l}\text { The Moodle system includes a chat, } \\
\text { forum, blog, and WiKi module.That can } \\
\text { realize the good interaction. }\end{array}$ \\
\hline
\end{tabular}


Administrators, teachers and students with clear rights fulfill one's own duty.
The Moodle system has a clear and complete function of level-to-level management.

Through the comparison of functions above, we believe that the powerful Moodle network teaching function can fully meet the requirements of project-case teaching environment.

\subsection{The Advantages of the Project-Case Teaching Platform Based on Moodle}

\subsubsection{To Support Multiple Platforms; Simple and Easy to Use}

The project-case teaching platform based on Moodle can be deployed on any platform that supports PHP such as Windows, Linux and even Mas OSX. etc. The server can be Apache, IIS, Nginx. It supports MySQL, PostgreSQL, Oracle and other database. Moodle system is simple and easy to use, and can well meet the requirements of the project-case teaching environment.

\subsubsection{Powerful Function; to Fully Mobilize Students' Subjective Initiative}

The platform based on Moodle can use all sorts of function modules to conveniently provide project or subproject that teaching needs and various teaching examples, especially in the WiKi. Each member of the team can modify the work of the other members of the group. The original file will be saved in the form of "history". A constant modification to the same work can make it gradually become perfect. This paper takes the course Theory and Technology of CAI as an example for the test. The instructor designs a group WiKi activity called "dragon New Year card". Four students in one group are asked to carry out the WiKi activity according to the sequence of selecting the course. The first student will run, modify and perfect a file. by analogy, until the last student completes the "team work", all aspects of the work has been relatively perfect. In this "game", the students' subjective initiative is fully mobilized. Learning becomes a fun.

\subsubsection{To Improve the Inquiry Learning and Develop Students' Innovative Ability:}

The teaching platform can break the limit of time and space. As long as there is network, students can learn and discuss related content. The teaching platform provides such module as chat, BBS .Besides, it is helpful for teachers and students to discuss and study a project. In that way it improves the inquiry learning. Under the environment of the teaching platform, students can learn autonomically under the guidance of teachers. It maintains the equality of instructors and students in personality. At the same time it gives students the opportunity to bring initiative into full play. Students' innovation ability is cultivated in the process of learning teaching examples, analyzing, planning, and implementing projects.

\section{Practice of the Project-Case Teaching Platform Based on Moodle}

In this paper, Moodle is deployed on the Windows system which is familiar to us. The purpose is to test the availability of Moodle. Environment configuration of the teaching platform is shown in Table 2 . 
Table 2. Environment Configuration

\begin{tabular}{|l|l|}
\hline The operating system & Windows XP \\
\hline The web server & Apache2..2.17 \\
\hline Database & MySQL5.5.8 \\
\hline PHP Environment & PHP5.3.5 \\
\hline Moodle open source code & Moodle2.6+ \\
\hline The browser & Mozilla Firefox \\
\hline
\end{tabular}

\subsection{Installation and Deployment of Teaching Platform}

First click on the "download" menu in Moodle's official website moodle.org, then select "standard Moodle package". When you enter the page, try to find identified blue font "Windows". After clicking on the font into the http://download.moodle.org/windows/ page, we can now choose MoodleWindowsInstaller - latest - 26 to download. The file contains some applications that can create Moodle running environment: Apache2.2.17, PHP5.3.5, MySQL5.5.8, Moodle 2.6 +. Rename the files Moodle, then decompress them for installation. The paper put the folder on the D disk. Run Moodle.exe after decompression. Then visit the 127.0.0.1 and enter the installation interface.

The first need for installation is to choose the language. We choose the simplified Chinese. The installation directory is D: $\backslash$ MOODLE\server\moodle. Because it is just the experimental stage, website address is http://127.0.0.1; the data directory is D: I MOODLE $\backslash$ server $\backslash$ moodle data. Then, the database settings page appears. Most of the data of Moodle system will be stored here. According to the prompts, click the "back" to complete this operation. Then the installation program will automatically check the server. Finally type the specific content in the ensuing administrator's account- setting page and home page setting to complete installation.

\subsection{The Main Operation of Teaching Platform}

\subsubsection{Website Administration}

After the installation, by typing http://127.0.0.1 in the Mozilla Firefox browser, we will be able to enter the home page of project-case teaching platform. Related settings can be done by selecting the corresponding menu, such as the clicking of "site administration" "appearance" - "theme" in the "theme selector", you can change the theme of the site, as shown in Figure 1.

\subsubsection{Course Administration}

Administrators or teachers can add new courses through the "course" option. The format of the course includes "community format ", "theme format", "week format". Teachers can set appropriate course format according to the specific teaching situation. According to the requirement of the project-case teaching, teachers can also add related resources or different kinds of activities to enrich course content. The resource module supports PDF, Word, Excel, PowerPoint, animation, video, audio and other file formats. Activity module includes chat, forum, WiKi, homework and so on.

\subsubsection{How Teachers Manage Students on the Platform}

After teachers enter the "user" module. They can add students into the course when needed. They can also cancel the students' enrollment according if necessary. Besides, they can build a small or large group etc. as shown in Figure 2. 


\section{The project-case teaching platform}

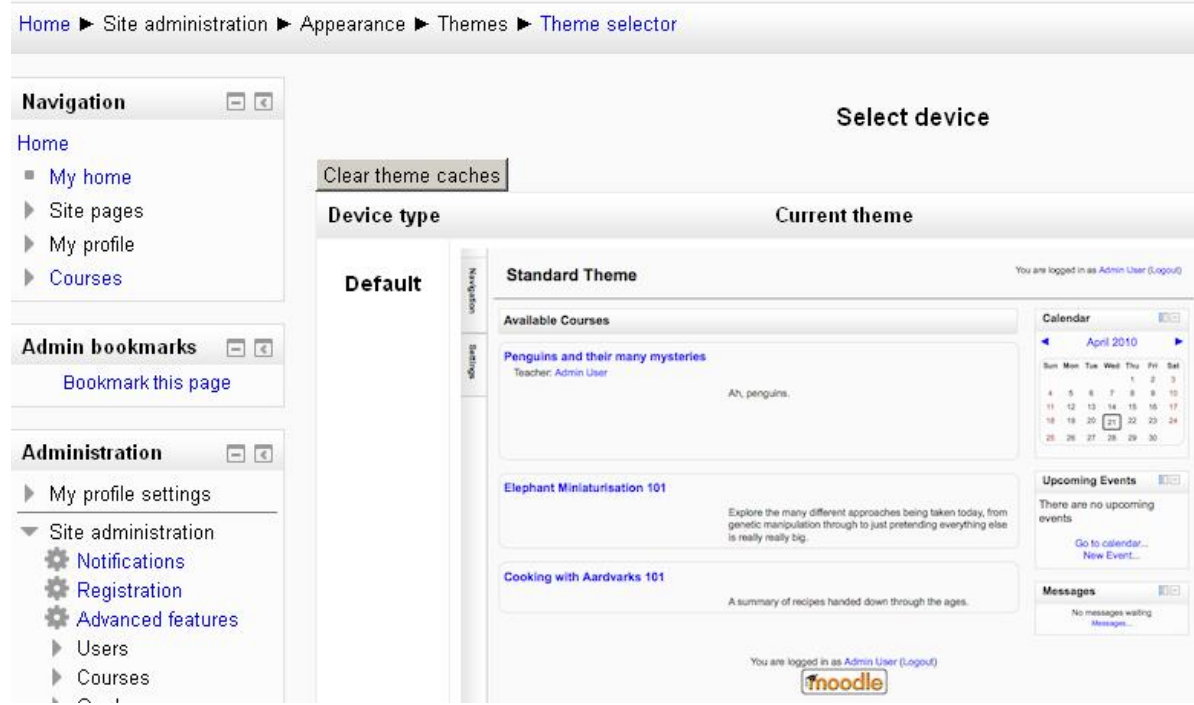

Figure 1. Theme Selector

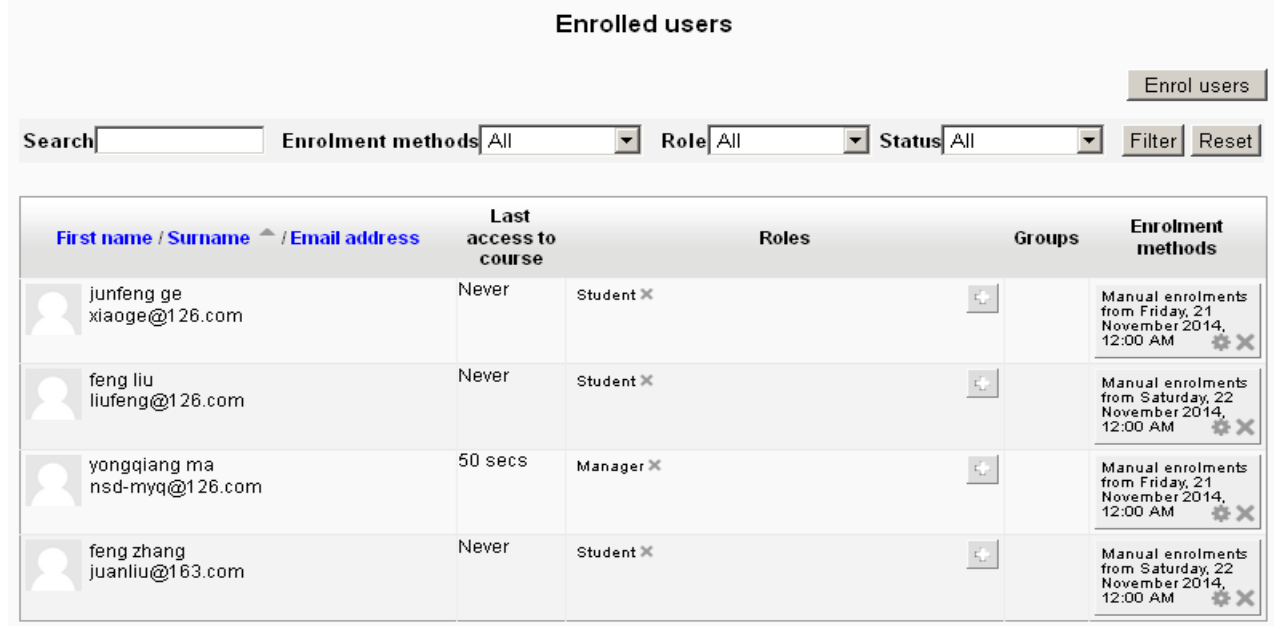

Figure 2. Add Students

\subsubsection{Test Management}

We can design examination papers of various courses by "test" option. The types of test questions can include choice, judgment and other kinds of questions. After the exams, the system automatically scores and output various transcripts.

\subsection{Assessment of the Project-Case Teaching Platform Based on Moodle}

On the basis of the project-case teaching platform based on Moodle, this paper takes the course Theory and Technology of CAI as an example to test small-scale users. 45 users are tested. All of them are undergraduates majoring in computer science and technology in grade 2011. According to the "teaching platform- using table", we find that most of the students (39) give positive response such as "prefer this kind of teaching mode", "greatly improve courseware- making ability and innovation ", "favor their autonomous learning and inquiry learning".

At the same time, some deficiencies are also found in the practical teaching. Although the function of course management in the teaching platform is very 
powerful, too many function modules, in a certain extent, reduce the usability of the system. Moreover, function of level-to-level management of the system is relatively complex. Last but not least, personalized theme design and second development of modules require certain technical ability. These defects are key problems in the process of future teaching and scientific research.

\section{References}

[1] Z. Mazhiqiang, "A Summary of Moodle Platform. Open Education Research, vol. 12, no. 10, (2007).

[2] L. Wangyanhua, "Teachers' Training Based on Moodle Platform”, Open Education Research, vol. 5, no. 91, (2008).

[3] P. Shanqing, W. Qin, "Introduction to Moodle in the application of the experimental teaching in colleges and universities", Experimental Technology and Management, vol. 10, no. 90, (2009).

[4] J. Hui and Y. Tanyanmei, "Based on Moodle open source software construction of college information literacy education network platform", Researches In Library Science, vol. 8, no. 26, (2011).

[5] L. Juan and D. Jinju, "Interaction between teachers and students on college students' study, the influence of Moodle platform based case study", China Educational Technology, vol. 5, no. 102, (2011).

[6] Wanglili, "Study on Teaching Moodle Platform of Higher Vocational Database Based on Mobile Cloud Computing", Techniques of Automation and Application, vol. 9, no. 24, (2014).

\section{Author}

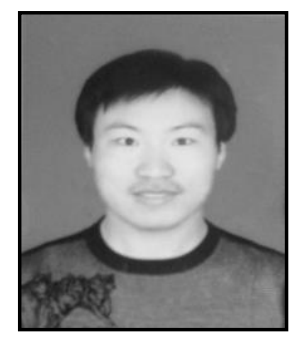

MaYongqiang, was born on February 27, 1982, in China, male, a teacher of Jining Normal University, Wulanchabu, Inner Mongolia, Master of Sciences, lecturer

Research Interests: Computer-aided Instruction, Multimedia Technology and Application, etc. 